\title{
LA PARENTELA DE MARÍA. CULTOS MARIANOS, SINCRETISMO E IDENTIDADES NACIONALES EN AMÉRICA LATINA
}

\section{Félix Baez-Jorge}

Xalapa, Biblioteca Universidad Veracruzana. 229 pp. 1994.

El título de este libro pone a pensar en las redes simbólicas y dc parentesco que algunas comunidades indigenas y campesinas latinoa. mericanas, establecen a través de sus vírgenes y santos. Sin embargo, en el trabajo de Baez-Jorge al contrario de encontrar una alternativa para descifrar los códigos profundos de los parentescos entre vírgenes y santos, se halla un problema de mayor envergadura: la relación entre vírgenes e identidades nacionales. La parentela a que se refiere surge de la variedad de advocaciones marianas que con significación nacional se esparcen sobre el mapa latinoamericano. Por eso en uno de los apéndices relacionó trescientas vírgenes exactamente, correspondientes a dieciséis países latinoamericanos y tres caribeños (p. 185 - 196).

Para desarrollar su trabajo escogió la centésima parte: tres vírgenes, cuyos casos estudia en tres capítulos independientes y analiza conjuntamente en el último capítulo que denominó "de las devociones marianas a las lealtades nacionales": Guadalupe-Tonantzin, Caridad-Ochún y Copacabana-Pachamama. Las seleccionó porque "constituyen poderosas entidades sincréticas que han concertado arcaicas creencias con los perfiles numinosos del culto mariano. Núcleos de devoción en torno a los cuales se han configurado identidades nacionales... trama numinosa de múltiples alcances en tanto que se relaciona con aspectos sustantivos, determinantes de lealtades e identidades de dimensión étnica." (p. 38) y porque estuvo como agregado cultural de México en Bolivia y Cuba. Ojalá que la visibilidad con que han sido dotadas esas tres marías, no las convierta en lugares comunes de los estudios de los fenómenos de reelaboración étnica y nacional de las vírgenes y santos.

Para el profesor Báez-Jorge, religión y política se conectan simbólicamente a través de los cultos marianos de carácter nacional. Además, es necesario no perder de vista que "los cultos marianos latinoamericanos nacen al amparo de las políticas coloniales y que su desarrollo no es resultado de la hegemonía canóniga de la iglesia, sino de procesos de incautación de lo sagrado concretado por las comunidades de creyentes que tiene en las mariofanías la posibilidad de disponer de deida- 
des inmanentes, factuales, propias, frente a las elaboradas concepciones teológicas propuestas por el clero." (p. 167).

La metodología del estudio, desde una perspectiva dinámica, da prioridad a los fenómenos sociales que se originaron a partir de la relación virgen-identidad nacional, subraya las fuerzas que determinaron su configuración, y sobre todo, realza aquellas que incidieron en sus cambios sustantivos, documentándolas etnológica, históricay sociológicamente. Impulsa un sentido, especialmente crítico, al analizar las formas simbólicas de resistencia emanadas de las advocaciones, y se asegura de no caer en un análisis institucional de las vírgenes. Y, finalmente, sitúa la información, los datos y el análisis en el marco de las tensiones y conflictos sociales, de tal manera que la explicación ofrezca las vinculaciones "entre los elementos simbólicos de carácter religioso, estableciendo su constancia, intensidad y articulación en los contextos sociales donde se han gestado, desarrollado y transformado." (p. 23) La aplicación de este método conduce al autor hacia un resultado, que a mi modo de ver, es un estudio de la alteridad colectiva, documentado con precisión histórica. El conocimiento que sustenta el estudio de Báez-Jorge aunque puede desmitificar el sitial inmaculado y evidenciar el uso de las devociones marianas con fines políticos y nacionalistas, incluso milita- ristas, mantiene e imprime un profundo respeto por las tres manifestaciones de la virgen, en tanto expresión cultural y religiosa.

Con La parentela de María, la ciencia obtiene un buen ejemplo y crgumento de cómo se modificaron los aportes religiosos prehispánicos e hispánicos y se transformaron en sustentos de identidades nacionales y en reelaboraciones simbólicas por apropiación de las poblaciones de os tres países estudiados. Sin que por ello signifique que la dimensión (el libro cierre las puertas a la observación del fenómeno en un contexto ımericano más amplio o también nás local.

La información sobre los tres casos marianos es extensa y lamentablemente no se puede dar cuenta de toda ella en esta reseña. Pero sí se puede decir que se sustenta en una amplia información teórica, documental y etnográfica que le permite al autor brindar un estudio lúcido, creativo y claro. Combina los rasgos telúricos de las culturas mexicanas, aymarás y yorubas, con universales femeninos de otra religiones, y los dos con hechos históricos reportados en documentación de primera mano y con información etnográfica novedosa. El texto refleja la perspectiva de lo vivido por el sujeto religioso, la vinculación crítica con los estudios sobre mariología, la utilización transparente del concepto de religiosidad popular, y la decidi- 
da visión que le imprime el profesor Báez-Jorge al fenómeno mariano estudiado, como manifestación sincrética - pues según él, toda relación entre virgen e identidad nacional se funda en articulaciones y contradicciones configuradas históricamente (p. 165ss).

Cierra el libro con una discusión abierta; así prefirió llamar a sus conclusiones. Discusión que tiene por ejes la capacidad de aglutinar identidades fragmentadas - al consolidarse las vírgenes como anclajes ideológicos de las formaciones nacionales (p. 159) - la función de "imágenes-memoria" que tienen las mariofanías, las que presenta como "aluviones simbólicos" y que entendí como un palimpsesto (p. 165), la manera como la relación virgen-identidad nacional expresa dialécticamente la mediación entre el pueblo y el poder como respuesta específica e histórica en la lucha por la hegemonía (p. 166), $y$, finalmente, la forma como se integran de manera particular a las tradiciones culturales de cada país las advocaciones religiosas.

Al finalizar su lectura el libro deja dos sensaciones: la primera, es que la religiosidad hacia las vírgenes ha cumplido un evidente papel en la vertebración de las sociedades nacionales latinoamericanas y por extensión de las locales. La segunda, es la necesidad de conocer con mayor detalle cómo se expresa la relación histórica entre virgen e identidad colectiva - sin perder de vista los contextos culturales e históricos, locales, regionales o nacionales - para avanzar en el conocimiento de tos procesos de alteridad colectiva de nuestra diversidad cultural.

Para terminar sólo resta decir que La parentela de María. Cultos marianos, sincretismo e identidades nacionales en América Latina, es un reconocimiento académico a George Balandier de principio a fin. Y que cuando nos enfrentamos a los procesos de alteridad colectiva o de cambio cultural en contextos de contacto intercultural o de luchas por hegemonías políticas, culturales y religiosas no podemos dejar de pensar que así como las sociedades se transforman en relación con otras, dentro de ellas "son permanentes los procesos de engendramiento cultural a partir de tres dimensiones convencionales de tiempo que son — según Balandier, citado por Báez-Jorge-_- "el pasado que funda y valida, el presente que opera por las prácticas codificadas de los agentes sociales, y el futuro que se anuncia como un riesgo inminente para garantizar la reproducción social" (p. 182).

\section{Carlos Vladimir Zambrano \\ Instituto Colombiano de Antropología}

